\title{
Fertilizer recommendations for maize production in the South Sudan and Sudano-Guinean zones of Benin
}

\author{
A. Saïdou • I. Balogoun · E. L. Ahoton · A. M. Igué · S. Youl · G. Ezui · \\ A. Mando
}

Received: 21 December 2016/ Accepted: 21 December 2017/Published online: 29 December 2017

(C) The Author(s) 2017. This article is an open access publication

\begin{abstract}
The present study aims to determine fertilizer $(\mathrm{N}-\mathrm{P}-\mathrm{K})$ recommendations for maize (Zea mays L.) on Acrisols (south Benin) and Ferric and Plintic Luvisols (centre Benin). Two years (2011 and 2012) experiment was conducted at Dogbo and Allada districts (southern) and Dassa (centre Benin). Six onfarm experiments were carried out to validate fertilizer rates simulated by the DSSAT model. The experimental design in each field was a completely randomized bloc with four replications and ten $\mathrm{N}-\mathrm{P}-\mathrm{K}$ rates:
\end{abstract}

A. Saïdou $(\bowtie) \cdot$ I. Balogoun · E. L. Ahoton Integrated Soil and Crop Management Research Unit, Laboratory of Soil Sciences, Department of Crop Sciences, Faculty of Agronomic Sciences, University of Abomey-Calavi, 01 BP 526 RP, Cotonou, Benin e-mail: saidoualiou@gmail.com

A. M. Igué

Laboratoire des Sciences du Sol, Eau et Environnement (LSSEE), Centre de Recherche d'Agonkanmey, Institut National des Recherches Agricoles du Bénin (INRAB), 01 BP 988 RP, Cotonou 01, Benin

\section{S. Youl} IFDC Burkina Faso, 11 BP 82 CMS, Ouagadougou 11, Burkina Faso

G. Ezui

c/o IITA, International Plant Nutrition Institute (IPNI), Ibadan, Nigeria

A. Mando

GRAD Consulting Group, 01 BP 6799, Ouagadougou 01, Burkina Faso
0-0-0 (control), 44-15-17.5 (standard fertilizer recommendation for maize), 80-30-40, 80-15-40, 80-30-25, 80-30-0, 69-30-40, 92-30-40, 69-1525 and $46-15-25 \mathrm{~kg} \mathrm{ha}^{-1}$. Treatments $44-15-17.5$ and 46-15-25 showed the lowest grain and stover yields. The observed maize grain yields were highly correlated with the estimated grain yields $\left(\mathrm{R}^{2}\right.$ values varied between 80 and $91 \%$ for growing season 2011 and between 68 and 94\% for growing season of 2012). The NRSME values varied between 12.54 and $22.56 \%$ (for growing season of 2011) and between 13.09 and $24.13 \%$ (for growing season of 2012). The economic analysis for the past 32 years (1980-2012) including the current experiment showed that $\mathrm{N}-\mathrm{P}-\mathrm{K}$ rates 80-30-25 (at Dogbo), 80-15-40 (at Allada) and 80-30-0 (at Dassa) were the best fertilizer recommendations as they presented the highest grain yields and the best return to investment per hectare. Nevertheless, 80-30-25 is advised for Dassa considering that sustainable maize production will require regular inputs of potassium. The 2 years of field experiments were not sufficient to derive biophysically optimal fertilizer recommendation rates for each site.

Keywords Soil fertility - Simulation - DSSAT · Acrisols · Ferric and Plintic Luvisols 


\section{Introduction}

Maize (Zea mays L.) has the highest global production of all cereals with $1,037,791,518$ tons grain produced (FAOSTAT 2014). From 1990 to 2005 in South, East, Central and West Africa countries, maize made up about $56 \%$ of the cultivated area (FAOSTAT 2007). About $50 \%$ of the population of Africa depends for their subsistance on maize as a staple food and source of carbohydrates, protein, iron, vitamin B and minerals (Zeller et al. 2006). Maize is becoming a cash crop (FAOSTAT 2013), which contributes to the improvement of farmers' livelihood. Based on these statistics, supporting maize production will ensure successful food security and will improve the economic growth of West African countries (Toléba-Séidou et al. 2015).

In Benin, maize is the principal staple food crop. It is the most consumed cereal ahead of rice and sorghum and plays major role for food security. Maize is also used for animal feed and constitutes farmers' principal source of income (Toléba-Séidou et al. 2015). Therefore, maize contributes for $6.54 \%$ to the agricultural Gross Domestic Product (GDP) (Adégbola and Arouna 2003). Maize is a strategic crop in Benin's economy as it provides employment in rural area (Saïdou et al. 2012). In general, maize cropping systems are heterogenous in the different agroecological zones (Diallo et al. 2012). Due to climate variability, short growing cycle maize varieties of 3 months are widely grown with attainable yield of $6 \mathrm{tha}^{-1}$ on station. The most limiting factors for maize cultivation in Benin are the erratic rainfall pattern and the low soil fertility (Saïdou et al. 2012; Balogoun et al. 2013; Igué et al. 2013). The main causes of the low soil fertility are low organic matter content, the low use of fertilizer, poor soil fertility management practices and monocropping (Saïdou et al. 2012; Balogoun et al. 2013). Typical farmer maize yields are low about $800 \mathrm{~kg} \mathrm{ha}^{-1}$ (Saïdou et al. 2003) and generally without fertilizer application.

Maize cultivation under soil conditions in Benin requires high quantity of nutrients $(\mathrm{N}$ and $\mathrm{P})$. There is therefore a need to develop adequate fertilizer recommendations in order to achieve the level of productivity that could meet the needs of the increasing population in the rural area. This implies an intensification of the production by addressing the main constraints including farmers' fertilization practices. In Benin, fertilizer use, as in many other countries of
West Africa, has been promoted to intensify crop production. Different crop fertilization practices have been proposed by research and extension services. Many fertilizer types were used for maize production such as: urea, diammonium phosphate (DAP) and various NPK forms (Adégbidi et al. 2000; Acakpo 2004). Furthermore, to be efficient in terms of crop yield improvement under farmer conditions, high yielding varieties must be used. The same fertilizer rates are recommended for all agroecological zones within the country. Such practices do not take into account soil types and the specificity of farmers' cropping systems and farm ecology. These recommended standard fertilizer rates are old. Therefore, there is a need to update this fertilizer recommendation for maize production regarding each agroecological zone of Benin, soil types, and the economic profitability for the farmer.

The best way to do this is through the establishment of long term field trials which are expensive and time consuming (Dzotsi 2002; Dzotsi et al. 2003). Alternatively, agricultural simulation models are one way to predict yield components in various agroecosystem to save time and reduce field trials. Agricultural simulation models are originally developed, calibrated and validated under different agroecological conditions, and their application in other specific conditions does guarantee reliabilibty (Miao et al. 2006; Thorp et al. 2007, 2008; DeJonge et al. 2007). The present research was carried out in the framework of the IFDC-Africa fertilizer research program in West Africa. The objectives of the study were to: (1) validate the effect of fertilizer rates simulated by the DSSAT model in the context of the agroecological zones in the South and Central Benin, and (2) propose an updated and profitable $\mathrm{N}-\mathrm{P}-\mathrm{K}$ rates for maize production for the South and Central Benin by using the CERES-Maize model in DSSAT.

\section{Materials and methods}

\section{Description of the study area}

The study covered two agroecological zones (AEZ) of the nine in Benin. The transitional Sudano-Guinean AEZ has rainy season from mid-April to October, where yam, cotton, maize, cassava and cashew trees are predominant in the crop rotation systems. Ferric 
and Plintic Luvisols (FAO 2006) are the dominant soil types. The Sudano-Guinean on "Terre de barre" AEZ located in the southern Benin has a sub-equatorial rainy season. The cropping systems are based mainly on slash and burn agriculture, maize and cassava are predominant crops in the cropping systems and soil types are Acrisols.

On-farm trials were used to validate fertilizer doses simulated by DSSAT model during two growing seasons (2011 and 2012) under farmers' conditions for maize production. Combining DSSAT and geographical information system (GIS), a fertilizer recommendation map for the south and central Benin was drawn using soil data base of the area (at 1:100,000 scale) established by Igué (2000) and Weller (2002). In the Sudano-Guinean on "Terre de barre" AEZ, Sékou and Attogon (municipality of Allada, Atlantique Department) and Dévé and Ayomi (municipality of Dogbo, Couffo Department) were selected villages for the onfarm experiments. In the transitional Sudano-Guinean AEZ (Central Benin), Gomé, Minifi and Dovi-Somè (all in the municipality of Dassa-Zoumé) in the Collines Department were selected. Villages and farmers were jointly identified with the local extension service. In total, six farmers' fields were selected to conduct the experiment. The municipality of Dogbo lies between latitude $6^{\circ} 47^{\prime} 56^{\prime \prime} \mathrm{N}$ and longitude $1^{\circ} 50^{\prime} 35^{\prime \prime} \mathrm{E}(58 \mathrm{msl})$ while the municipality of Allada lies between latitude $6^{\circ} 39^{\prime} 52^{\prime \prime} \mathrm{N}$ and longitude $2^{\circ} 09^{\prime} 30^{\prime \prime} \mathrm{E}$. Dassa municipality lies between latitude $7^{\circ} 50.4^{\prime} \mathrm{N}$ and $2^{\circ} 10^{\prime} \mathrm{E}$.

Field experiments and simulation studies

Two year on-farm experiments were conducted during the rainy season (from April to June). In each AEZ, farmers' fields were selected based on the result of the previous crops. Fields were chosen where no fertilizer was applied before. In each farmer's field, a randomized complete block design with 4 replications and 10 treatments was carried out. Plots' size of $8 \mathrm{~m} \times 5.6 \mathrm{~m}$ $\left(44.8 \mathrm{~m}^{2}\right)$ was used. All experimental plots were farmer-managed. The maize variety used was EVDT 97 STRW (90 days growing cycle and attainable yield of $6 \mathrm{tha}{ }^{-1}$ ) planted at the beginning of April of each year at a spacing of $80 \mathrm{~cm} \times 40 \mathrm{~cm}$ (two seeds per hole leading to a planting density of 62,500 plants $\mathrm{ha}^{-1}$ ). The same maize seed and fertilizer were used by all of the farmers' selected. Planting and weeding operations were left up to the farmers after providing them with general guidelines. The nitrogen source $(\mathrm{N})$ was urea $(46 \% \mathrm{~N})$; phosphorus (P) was from triple super phosphate (TSP, $46 \% \mathrm{P}_{2} \mathrm{O}_{5}$ ) and potassium $(\mathrm{K})$ was from potassium chlorite $(\mathrm{KCl}$, $60 \% \mathrm{~K}_{2} \mathrm{O}$ ).

Four levels of $\mathrm{N}\left(0,40,80\right.$ and $\left.120 \mathrm{~kg} \mathrm{ha}^{-1}\right)$, three levels of $\mathrm{P}\left(0,30\right.$ and $\left.60 \mathrm{~kg} \mathrm{ha}^{-1}\right)$ and three levels of $\mathrm{K}$ $\left(0,40\right.$ and $\left.80 \mathrm{~kg} \mathrm{ha}^{-1}\right)$ leading to 36 combinations of $\mathrm{N}, \mathrm{P}$ and $\mathrm{K}$ simulated were tested. These 36 combinations were put on the fertilizer recommendation maps of the south and central Benin (Ezui et al. 2011; Igué et al. 2013). The simulations were performed on the scale of 1:100,000 for both AEZ. From these, two simulated fertilizer rates (80-30-40 and 80-30-0) were selected for the two AEZ. In addition to these two simulated rates, the control $(0-0-0)$ and the standard fertilizer recommendation dose (44-15-17.5) and six more N-P-K combinations were considered: 80-15$40,80-30-25,69-30-40,92-30-40,69-15-25$ and $46-15-25$.

In total, ten fertilizer ( $\mathrm{N}-\mathrm{P}-\mathrm{K}$ combination) rates were validated during the on-farm experiment. Thus, the treatments were the following fertilizer $\mathrm{N}-\mathrm{P}-\mathrm{K}$ rates: $0-0-0$ (control), 44-15-17.5 (standard fertilizer recommendation for maize), 80-30-40, 80-15-40, 80-30-25, 80-30-0, 69-30-40, 92-30-40, 69-15-25 and $46-15-25 \mathrm{~kg} \mathrm{ha}^{-1}$. The standard fertilizer recommendation for maize consists of $150 \mathrm{~kg} \mathrm{ha}^{-1}$ NPK 14-23-14 and $50 \mathrm{~kg} \mathrm{ha}^{-1}$ urea (Dugué 2010).

Composite soil samples were collected at $0-20 \mathrm{~cm}$ depth after plowing and before fertilizer application. Fertilizer application was done by researcher team. Phosphorus and potassium were applied just before sowing maize. Urea was applied 15 days after sowing (DAS) and 45 DAS (after the second weeding period) about $5 \mathrm{~cm}$ from the plant. Maize was harvested at physiological maturity. Maize stover was cut at soil surface for biomass yield after leaving the two border lines and two border seed holes. Cobs and stover were weighed with hand scale and samples of each part taken were weighed with an electronic scale and dry matter determined after drying at $60{ }^{\circ} \mathrm{C}$ for $72 \mathrm{~h}$ in the oven at laboratory. Soil chemical analyzes were performed at the Laboratory of Soil Science, Water and Environment of Benin National Research Institute (LSSEE/INRAB).

Soil samples were analysed for $\mathrm{pH}$ (water) (using a glass electrode in 1:2.5 v/v soil solution), organic 
carbon (Walkley and Black method), total nitrogen (Kjeldahl digestion method in a mixture of $\mathrm{H}_{2} \mathrm{SO}_{4}$, selenium followed by distillation and titration), available phosphorus (Bray 1 method) and exchangeable potassium (1 N ammonium acetate at $\mathrm{pH} 7$ method, after which $\mathrm{K}^{+}$was determined by flame photometer).

The statistical analyses were performed using SAS v. 9.2 packages. Observed maize grain and stover yield of each growing season and within an AEZ were subjected to a one-way analysis of variance (ANOVA). The Student Newman-Keuls test was performed for means separation at a significance levels of $P<0.05$.

Decision Support System for Agrotechnology Transfer (DSSAT v 4.5) was used for the simulations. The model requires minimum of input data including: name and geographical position of the field (longitude, latitude and altitude), previous crops grown on the field, crop management informations (tillage, planting date, planting method, sowing density and fertilizer application dates). Plant genetic coefficients were determined through GLUE program of DSSAT (He et al. 2010). The genetic coefficients used for the maize cultivar are presented in Table 1 . Soil analytical characterisitics used were: $\mathrm{pH}$ (water), organic carbon, available phosphorus (P-Bray 1), total nitrogen and exchangeable potassium. Weather data from 1981 to 2010 were used for the initial fertilizer dose simulation and daily data of 2011 and 2012 were used for the onfarm validation of the fertilizer recommendation. These data included precipitation, minimum and maximum temperatures and solar radiation. They were collected from ASECNA (Agence pour la Sécurité de la Navigation Aérienne en Afrique et à Madagascar) synoptic station of Cotonou, Bohicon and Savè close to the research area. Field results were used to determine genetic coefficients of maize (Table 1) and these model inputs were integrated to provide a framework for simulating and analyzing the outputs. The calibration procedure of the CERESMaize model consisted of making initial estimate of the genetic coefficient and running the model interactively, so that simulated values match as closely as possible the measured data. The thermal time was computed using algorithm developed by Jones and Kiniry (1986) which assumes development rate increases as a linear function of temperature between the base temperatures $\left(8^{\circ} \mathrm{C}\right)$ and an optimal temperature of $34{ }^{\circ} \mathrm{C}$. Based on the phenological data collected, genetic coefficients (P1, P5 and PHINT) were calculated from daily temperature data collected for the study area. These coefficients were fine-tuned to attain appreciable agreement between simulated and observed values for anthesis and physiological stages. The genetic coefficients for G2 and G3 were determined by iteration of model simulations based on data collected under limited growth stress condition. Iterations were repeated until there was an appreciable agreement between simulated and observed value for the yield data using a 1:1 line for each season of production. Biophysical and economic analyses were also performed in order to determine a series of costeffective options.

Correlation coefficients (Singh and Wilkens 2001) were determined to assess gaps between simulated yields and those observed from the field, Root Mean Square Error (RMSE) (Du Toit et al. 2001) and Normalize Root Mean Square Error (NRMSE) (Loague and Green 1991; Jamieson et al. 1991) were used to assess the performance of the model. The financial analysis was done by integrating as input in the model production cost and maize price collected in

Table 1 Genetic coefficients used for modeling the EVDT 97 STRW maize variety in CERES-maize model at the three sites

\begin{tabular}{ll}
\hline Coefficients & Definition \\
\hline P1 & $\begin{array}{l}\text { Thermal time from seedling emergence to the end of the juvenile phase during which the plant is not } \\
\text { responsive to changes in photoperiod (expressed in degree days) }\end{array}$ \\
P2 & $\begin{array}{l}\text { Extent to which crop development (expressed as days) is delayed for each hour increase in photoperiod above } \\
\text { the optimal photoperiod }\end{array}$ \\
P5 & Thermal time from silking to physiological maturity (expressed in degree days above a base temperature of \\
& $8{ }^{\circ} \mathrm{C}$ )
\end{tabular}


the study area. Maize price in the market during the harvest period was FCFA kg-1 200, 225 and 175 (US \$ $1=$ FCFA 550) respectively at Dogbo, Allada and Dassa. The price of maize seed was FCFA kg-1 450 and the price of fertilizer was FCFA kg ${ }^{-1} 717,1393$ and 703 respectively for $\mathrm{N}, \mathrm{P}$ and $\mathrm{K}$. The cost of labour was also assessed and introduced in the model for the economic analysis. The cost of clearing in the area were FCFA ha ${ }^{-1} 25,000 ; 22,500$ and 20,000 respectively at Dogbo, Allada and Dassa; ploughing FCFA $\mathrm{ha}^{-1} 40,000,50,000$ and 62,500 respectively at Dogbo, Allada and Dassa; sowing: FCFA ha ${ }^{-1} 10,000$ (at Dogbo) and 7500 (at Allada and Dassa); weeding: FCFA ha ${ }^{-1} 33,750$ (at Dogbo) and 17,500 (at Allada and Dassa) and harvesting: FCFA ha ${ }^{-1} 37,500 ; 11,250$ and 10,000 respectively at Dogbo, Allada and Dassa.

After obtaining the distribution of economic returns, strategic analysis was done to compare fertilizer rates in economic terms, taking into account weather and pricerelated risks from 1980 to 2012. This analysis allowed the evaluation of the long-term rainfall effect on the simulated yields (Jones et al. 2003). It was done by examining the mean-variance plots of gross margins or net returns per hectare, or using the mean-Gini stochastic dominance. This analysis leads to the choice of the best and efficient fertilizer option. In more detail, the mean-Gini stochastic dominance as developed by Fosu et al. (2012) assumes that:

for two risky prospects $\mathrm{A}$ and $\mathrm{B}, \mathrm{A}$

dominate $\mathrm{B}$ if $\mathrm{E}(\mathrm{A})>\mathrm{E}(\mathrm{B})$

or if $\mathrm{E}(\mathrm{A})-\mathrm{F}(\mathrm{A})>\mathrm{E}(\mathrm{B})-\mathrm{F}(\mathrm{B})$

where $\mathrm{E}(\cdot)$ is the mean, and $\mathrm{F}(\cdot)$ the Gini coefficient of distributions A and B. F is half the value of Gini's mean difference. It is a measure of the spread of a probability distribution.

The most economically superior fertilizer rates were then selected by this process.

\section{Results}

Soil chemical parameters in each agroecological zone

Soil chemical analysis of the different farms investigated before planting the maize revealed the following properties: $\mathrm{pH}$ (water) of 6.51, 6.58 and 6.4 (respectively for Dogbo, Allada and Dassa); organic C of $4.45,8.08$ and $3.99 \mathrm{~g} \mathrm{~kg}^{-1}$ (respectively for Dogbo, Allada and Dassa); total $\mathrm{N}$ of $0.74,0.64$ and $0.42 \mathrm{~g} \mathrm{~kg}^{-1}$ (respectively for Dogbo, Allada and Dassa); available $\mathrm{P}$ of $82.75,53.29$ and $82.75 \mathrm{mg} \mathrm{kg}^{-1}$ (respectively for Dogbo, Allada and Dassa) and exhangeable K 1.05, 1.81 and $1.44 \mathrm{cmol}$ $\mathrm{kg}^{-1}$. In general, the soils of the study area are slightly acid and low in organic matter $(\mathrm{C} / \mathrm{N}$ ratio of the acrisols varying between 14.06 to 22.42 and that of the Ferric and Plintic Luvisols is 25.95). The consequence of this high $\mathrm{C} / \mathrm{N}$ ratio is a low level of total $\mathrm{N}$ which seems to be with $\mathrm{P}$ the most limiting nutrients.

Calibration and validation of the model: observed versus simulated maize grain and stover yields in each agroecological zone

In general, the observed maize grain and stover yields of the different $\mathrm{N}-\mathrm{P}-\mathrm{K}$ combinations, except for the fertilizer rate 46-15-25 (in 2011), were significantly different compared to the standard fertilizer recommendation (44-15-17.5) at Dogbo (Table 2). A yield increase of 1.4 compared with the standard recommendation was observed. During this growing season, no significant differences were noticed among the $\mathrm{N}-$ $\mathrm{P}-\mathrm{K}$ fertilizer rates but all the treatments had significantly increased yields by a factor of 1.5-2 respectively compared to control (0-0-0). The stover yields followed the same trend as the grain yields. In the cropping season 2012, the $\mathrm{N}-\mathrm{P}-\mathrm{K}$ fertilizer rates studied showed significant effect on both grain and stover yields compared to the control. The lowest values were found on the control field while the highest with 80-30-25, 92-30-40 and 80-15-40 at Dogbo, Allada and Dassa respectively. The standard fertilizer recommendation and the N-P-K rate 46-1525 showed lowest stover yields compared to the other treatments. Thus, maize grain and stover yields were increased by $1.4-1.6,1.3-2$ and 1.1-1.4 respectively in Dogbo, Allada and Dassa.

Data simulated by DSSAT-CERES model were compared with the real data obtained in 2011 and 2012 in the field, in order to determine the suitability of making site specific fertilizer recommendations. In general, maize grain yields simulated by the model were close to that measured in the field (Table 3). 
Table 2 Average $( \pm \mathrm{SE})$ value of the observed maize grain yield and stover mass regarding the different sites and $\mathrm{N}-\mathrm{P}-\mathrm{K}$ combinations in the growing season of 2011 and 2012

\begin{tabular}{|c|c|c|c|c|c|}
\hline \multirow[t]{2}{*}{ Sites } & \multirow[t]{2}{*}{ Treatments } & \multicolumn{2}{|l|}{2011} & \multicolumn{2}{|l|}{2012} \\
\hline & & Grain yield (t MS ha ${ }^{-1}$ ) & Stover yield (t MS ha ${ }^{-1}$ ) & Grain yield (t MS ha ${ }^{-1}$ ) & Stover yield (t MS ha ${ }^{-1}$ ) \\
\hline \multirow[t]{10}{*}{ Dogbo } & $0-0-0$ & $1.70 \pm 0.03 \mathrm{c}$ & $2.99 \pm 0.17 \mathrm{c}$ & $1.16 \pm 0.16 \mathrm{~d}$ & $1.98 \pm 0.29 \mathrm{~b}$ \\
\hline & $44-15-17.5$ & $2.25 \pm 0.15 \mathrm{~b}$ & $3.73 \pm 0.37 \mathrm{~b}$ & $2.53 \pm 0.20 \mathrm{c}$ & $4.53 \pm 0.48 \mathrm{a}$ \\
\hline & $80-30-40$ & $2.77 \pm 0.15 \mathrm{a}$ & $4.55 \pm 0.29 \mathrm{ab}$ & $3.64 \pm 0.22 \mathrm{ab}$ & $5.13 \pm 0.40 \mathrm{a}$ \\
\hline & $80-15-40$ & $2.97 \pm 0.16 \mathrm{a}$ & $4.21 \pm 0.24 \mathrm{ab}$ & $3.61 \pm 0.23 \mathrm{ab}$ & $4.93 \pm 0.41 \mathrm{a}$ \\
\hline & $80-30-25$ & $3.04 \pm 0.12 \mathrm{a}$ & $4.98 \pm 0.17 \mathrm{a}$ & $3.96 \pm 0.20 \mathrm{a}$ & $5.18 \pm 0.42 \mathrm{a}$ \\
\hline & $80-30-0$ & $3.06 \pm 0.14 \mathrm{a}$ & $4.44 \pm 0.24 \mathrm{ab}$ & $3.69 \pm 0.27 \mathrm{ab}$ & $4.64 \pm 0.34 \mathrm{a}$ \\
\hline & $69-30-40$ & $2.97 \pm 0.11 \mathrm{a}$ & $4.50 \pm 0.32 a b$ & $3.45 \pm 0.16 \mathrm{ab}$ & $4.81 \pm 0.47 \mathrm{a}$ \\
\hline & $92-30-40$ & $2.99 \pm 0.12 \mathrm{a}$ & $4.51 \pm 0.08 \mathrm{ab}$ & $3.72 \pm 0.20 \mathrm{ab}$ & $5.23 \pm 0.57 \mathrm{a}$ \\
\hline & $69-15-25$ & $3.09 \pm 0.13 \mathrm{a}$ & $4.46 \pm 0.23 \mathrm{ab}$ & $2.95 \pm 0.14 \mathrm{bc}$ & $4.42 \pm 0.37 \mathrm{a}$ \\
\hline & $46-15-25$ & $2.56 \pm 0.20 \mathrm{ab}$ & $4.29 \pm 0.14 \mathrm{ab}$ & $2.82 \pm 0.15 \mathrm{bc}$ & $4.23 \pm 0.46 \mathrm{a}$ \\
\hline \multirow[t]{10}{*}{ Allada } & $0-0-0$ & $1.00 \pm 0.12 \mathrm{~b}$ & $2.20 \pm 0.29 \mathrm{~b}$ & $0.96 \pm 0.15 \mathrm{~d}$ & $2.03 \pm 0.22 \mathrm{c}$ \\
\hline & $44-15-17.5$ & $1.90 \pm 0.14 \mathrm{a}$ & $3.86 \pm 0.22 \mathrm{a}$ & $1.32 \pm 0.13 \mathrm{~cd}$ & $2.56 \pm 0.22 \mathrm{bc}$ \\
\hline & $80-30-40$ & $2.08 \pm 0.10 \mathrm{a}$ & $4.77 \pm 0.39 \mathrm{a}$ & $2.14 \pm 0.13 \mathrm{~b}$ & $3.29 \pm 0.22 \mathrm{ab}$ \\
\hline & $80-15-40$ & $2.09 \pm 0.11 \mathrm{a}$ & $4.56 \pm 0.23 \mathrm{a}$ & $1.85 \pm 0.17 \mathrm{bc}$ & $3.00 \pm 0.37 \mathrm{abc}$ \\
\hline & $80-30-25$ & $1.98 \pm 0.10 \mathrm{a}$ & $4.35 \pm 0.23 \mathrm{a}$ & $2.03 \pm 0.14 \mathrm{~b}$ & $3.43 \pm 0.41 \mathrm{ab}$ \\
\hline & $80-30-0$ & $2.04 \pm 0.20 \mathrm{a}$ & $3.94 \pm 0.36 \mathrm{a}$ & $1.92 \pm 0.19 \mathrm{bc}$ & $3.50 \pm 0.31 \mathrm{ab}$ \\
\hline & $69-30-40$ & $2.21 \pm 0.06 \mathrm{a}$ & $4.68 \pm 0.23 \mathrm{a}$ & $1.93 \pm 0.14 \mathrm{bc}$ & $3.84 \pm 0.28 \mathrm{ab}$ \\
\hline & $92-30-40$ & $2.10 \pm 0.13 \mathrm{a}$ & $3.95 \pm 0.31 \mathrm{a}$ & $2.62 \pm 0.33 \mathrm{a}$ & $3.93 \pm 0.43 \mathrm{a}$ \\
\hline & $69-15-25$ & $1.87 \pm 0.12 \mathrm{a}$ & $3.65 \pm 0.26 \mathrm{a}$ & $1.57 \pm 0.12 \mathrm{bc}$ & $3.11 \pm 0.21 \mathrm{abc}$ \\
\hline & $46-15-25$ & $1.74 \pm 0.13 \mathrm{a}$ & $3.52 \pm 0.23 \mathrm{a}$ & $1.41 \pm 0.14 \mathrm{~cd}$ & $2.96 \pm 0.23 \mathrm{abc}$ \\
\hline \multirow[t]{10}{*}{ Dassa } & $0-0-0$ & $1.44 \pm 0.08 \mathrm{~b}$ & $2.81 \pm 0.19 \mathrm{~b}$ & $0.88 \pm 0.09 \mathrm{c}$ & $1.70 \pm 0.38 \mathrm{~b}$ \\
\hline & $44-15-17.5$ & $1.93 \pm 0.06 \mathrm{ab}$ & $3.59 \pm 0.19 \mathrm{ab}$ & $1.68 \pm 0.13 \mathrm{ab}$ & $2.61 \pm 0.32 \mathrm{ab}$ \\
\hline & $80-30-40$ & $2.58 \pm 0.21 \mathrm{a}$ & $4.74 \pm 0.47 \mathrm{a}$ & $2.11 \pm 0.19 \mathrm{ab}$ & $3.37 \pm 0.41 \mathrm{a}$ \\
\hline & $80-15-40$ & $2.45 \pm 0.15 \mathrm{a}$ & $4.76 \pm 0.37 \mathrm{a}$ & $2.30 \pm 0.21 \mathrm{a}$ & $3.77 \pm 0.57 \mathrm{a}$ \\
\hline & $80-30-25$ & $2.55 \pm 0.28 \mathrm{a}$ & $4.60 \pm 0.31 \mathrm{a}$ & $2.15 \pm 0.23 \mathrm{a}$ & $3.54 \pm 0.31 \mathrm{a}$ \\
\hline & $80-30-0$ & $2.34 \pm 0.16 \mathrm{a}$ & $4.08 \pm 0.32 \mathrm{a}$ & $2.04 \pm 0.14 \mathrm{ab}$ & $3.27 \pm 0.31 \mathrm{a}$ \\
\hline & $69-30-40$ & $2.38 \pm 0.20 \mathrm{a}$ & $4.36 \pm 0.44 \mathrm{a}$ & $1.89 \pm 0.13 \mathrm{ab}$ & $3.23 \pm 0.22 \mathrm{a}$ \\
\hline & $92-30-40$ & $2.58 \pm 0.21 \mathrm{a}$ & $4.67 \pm 0.30 \mathrm{a}$ & $2.03 \pm 0.14 \mathrm{ab}$ & $3.50 \pm 0.38 \mathrm{a}$ \\
\hline & $69-15-25$ & $2.20 \pm 0.10 \mathrm{a}$ & $4.08 \pm 0.13 \mathrm{a}$ & $2.11 \pm 0.19 \mathrm{ab}$ & $3.46 \pm 0.34 \mathrm{a}$ \\
\hline & $46-15-25$ & $2.43 \pm 0.16 \mathrm{a}$ & $4.31 \pm 0.32 \mathrm{a}$ & $1.39 \pm 0.11 \mathrm{~b}$ & $2.59 \pm 0.21 \mathrm{ab}$ \\
\hline
\end{tabular}

In a column mean followed by the same alphabetic letters are not significantly different $(P>0.05)$, Student Newman-Keuls test

Performance of the model

Results of the $t$ test for paired sample analysis, showed significant $(P<0.05$ and $P<0.001)$ difference between mean value of observed and simulated maize grain yields in Dogbo and Dassa during both growing seasons (2011 and 2012). The model has slightly underestimated maize grain yields at Dassa (growing season of 2011) and Dogbo (growing season of 2012) while data predicted by the model fit well with that of
Allada during the growing season of 2012 (Table 4). Furthermore, it was noticed that, the observed maize grain yields were highly correlated with estimated values by the model. The $\mathrm{R}^{2}$ values varied between 80 and $91 \%$ (for the growing season of 2011) and 68 and 94\% (for the growing season of 2012). The NRSME values between the observed and simulated maize grain yields varied between 12.54 and $22.56 \%$ (for the growing season of 2011) and between 13.09 and $24.13 \%$ (growing season of 2012). 
Table 3 Observed and simulated maize grain yields $\left(\mathrm{kg} \mathrm{ha}^{-1}\right)$ for 2011 and 2012 growing seasons regarding $\mathrm{N}-\mathrm{P}-\mathrm{K}$ nutrient combinations at Dogbo, Allada and Dassa sites in Benin

\begin{tabular}{|c|c|c|c|c|c|}
\hline \multirow[t]{2}{*}{ Sites } & \multirow[t]{2}{*}{ Treatments } & \multicolumn{2}{|l|}{2011} & \multicolumn{2}{|l|}{2012} \\
\hline & & Simulated & Observed & Simulated & Observed \\
\hline \multirow[t]{11}{*}{ Dogbo } & $0-0-0$ & 870 & 1700 & 910 & 1160 \\
\hline & $44-15-17.5$ & 2048 & 2250 & 2066 & 2530 \\
\hline & $80-30-40$ & 2917 & 2770 & 2784 & 3640 \\
\hline & $80-15-40$ & 2917 & 2970 & 2784 & 3610 \\
\hline & $80-30-25$ & 2917 & 3040 & 2784 & 3960 \\
\hline & $80-30-0$ & 2917 & 3060 & 2784 & 3690 \\
\hline & $69-30-40$ & 2736 & 2970 & 2627 & 3450 \\
\hline & $92-30-40$ & 3078 & 2990 & 2929 & 3720 \\
\hline & $69-15-25$ & 2736 & 3090 & 2627 & 2950 \\
\hline & $46-15-25$ & 2110 & 2560 & 2124 & 2820 \\
\hline & Value for comparison & 2632.3 & 2632.3 & 2797.5 & 2797.5 \\
\hline \multirow[t]{11}{*}{ Allada } & $0-0-0$ & 232 & 1000 & 474 & 960 \\
\hline & $44-15-17.5$ & 1646 & 1900 & 1571 & 1310 \\
\hline & $80-30-40$ & 2071 & 2080 & 2083 & 2130 \\
\hline & $80-15-40$ & 2059 & 2090 & 2083 & 1850 \\
\hline & $80-30-25$ & 2058 & 1980 & 2077 & 2030 \\
\hline & $80-30-0$ & 2137 & 2004 & 2080 & 1920 \\
\hline & $69-30-40$ & 2181 & 2210 & 1940 & 1920 \\
\hline & $92-30-40$ & 2056 & 2100 & 2140 & 2620 \\
\hline & $69-15-25$ & 1981 & 1870 & 1933 & 1570 \\
\hline & $46-15-25$ & 2087 & 1740 & 1576 & 1410 \\
\hline & Value for comparison & 1874.1 & 1874.1 & 1783.9 & 1783.9 \\
\hline \multirow[t]{11}{*}{ Dassa } & $0-0-0$ & 931 & 1440 & 711 & 880 \\
\hline & $44-15-17.5$ & 1740 & 1930 & 1659 & 1680 \\
\hline & $80-30-40$ & 1943 & 2580 & 1861 & 2110 \\
\hline & $80-15-40$ & 1943 & 2450 & 1861 & 2300 \\
\hline & $80-30-25$ & 1943 & 2550 & 1861 & 2150 \\
\hline & $80-30-0$ & 1943 & 2340 & 1861 & 2040 \\
\hline & $69-30-40$ & 1905 & 2380 & 1853 & 1890 \\
\hline & $92-30-40$ & 1940 & 2580 & 1863 & 2030 \\
\hline & $69-15-25$ & 1905 & 2200 & 1853 & 2110 \\
\hline & $46-15-25$ & 1753 & 2430 & 1702 & 1390 \\
\hline & Value for comparison & 2041.3 & 2041.3 & 1783.3 & 1783.3 \\
\hline
\end{tabular}

Seasonal and biophysical analysis

A seasonal analysis of 32 years (1980-2012) was done based on the observed maize grain yields for the different N-P-K combinations (Fig. 1). In general, it was observed from the field data that, maize grain yields are related to the variation of the $\mathrm{N}$ rates. With an increase of $\mathrm{N}$ rate of $12 \mathrm{~kg} \mathrm{ha}^{-1}, 21.1 \mathrm{~kg} \mathrm{ha}^{-1}$ of maize grain yield was obtained.
From Fig. 1, it is also observed that at $75 \%$ cumulative probability, at Dogbo, the maximum average maize grain yields of 750, 1750, 2300 and $2500 \mathrm{~kg} \mathrm{ha}^{-1}$ were obtained when respectively $0-0$ $0,46-15-25,69-30-40$ and 80-30-40 fertilizer rates, were applied. At Allada, the average maize grain yields of $750,1825,2200$ and $2250 \mathrm{~kg} \mathrm{ha}^{-1}$ were obtained when respectively, $0-0-0,46-15-25$, 69-30-40 and 92-30-40 fertilizer rates, were applied. Finally, at Dassa, 1500, 2250, 2300 and $2650 \mathrm{~kg} \mathrm{ha}^{-1}$ 
Table 4 Comparison between the observed and simulated maize yield parameters $\left(\mathrm{kg} \mathrm{ha}^{-1}\right)$ in 2 years (2011 and 2012) at Dogbo and Allada (Sudano-Guinean zone on terre de barre) and Dassa (transitional Sudano-Guinean zone)

\begin{tabular}{|c|c|c|c|c|c|c|}
\hline \multirow[t]{2}{*}{ Variables } & \multicolumn{3}{|l|}{2011} & \multicolumn{3}{|l|}{2012} \\
\hline & Dogbo & Allada & Dassa & Dogbo & Allada & Dassa \\
\hline Observed $\left(\mathrm{kg} \mathrm{ha}^{-1}\right)$ & 2740 & 1897 & 2288 & 3153 & 1772 & 1858 \\
\hline Simulated $\left(\mathrm{kg} \mathrm{ha}^{-1}\right)$ & 2525 & 1851 & 1795 & 2442 & 1796 & 1708 \\
\hline MD & $-215^{*}$ & $-46 \mathrm{~ns}$ & $-493 * * *$ & $-711 * * *$ & $24 \mathrm{~ns}$ & $-150 *$ \\
\hline Ratio & 0.90 & 0.94 & 0.78 & 0.78 & 1.01 & 0.93 \\
\hline r-Square $(\%)$ & 91 & 86 & 80 & 94 & 68 & 78 \\
\hline RMSE (\%) & 343.51 & 285.42 & 0.675 & 760.81 & 279.06 & 243.30 \\
\hline NRMSE (\%) & 12.54 & 15.05 & 22.56 & 24.13 & 15.75 & 13.09 \\
\hline
\end{tabular}

ns $=P>0.05 ; *=P<0.05 ; * * *=P<0.001$

of maize grain yields were obtained when respectively, 0-0-0, 44-15-17.5, 69-30-40 and 92-30-40 fertilizer rates, were applied.

Economic and strategic analysis

In order to determine fertilizer $\mathrm{N}-\mathrm{P}-\mathrm{K}$ rates to be proposed for maize cultivation, an economic analysis was done (Table 5) based on mean-Gini dominance analysis. This economic strategic analysis for the past 32 years showed that fertilizer rates 80-30-25, 80-15-40 and 80-30-0 respectively for the sites of Dogbo, Allada and Dassa, were the economically superior fertilizer recommendations as they presented the highest return to investment per hectare and the highest efficiency. The model suggested no application of $\mathrm{K}$ to the soil at the Dassa site (dominated by Ferric and Plintic Luvisols). To avoid this long-term unsustainable option the fertilizer rate 80-30-25 (with a net return to investment per hectare of FCFA 309708.7 against $315,749.6$ for fertilizer rate $80-30$ 0 ) would be economically sound and viable for soil fertility management. There was a similarity between fertilizer rates determined from the seasonal and biophysical analysis and the economic analysis for the Dogbo site.

\section{Discussion}

Soil fertility and maize productivity in south and central Benin

The soil analysis showed low soil fertility for the Ferric and Plintic Luvisols (central) and the Acrisols (south) as is typical for most Sub-Saharan African soils. The main characteristic of both soils is their low organic matter level which was also mentioned by several studies (Sanchez et al. 1989; Giller 2002; Saïdou et al. 2003). The high mineralisation rate of the organic matter (Pieri 1989) creates a lack of nitrogen in these soils. The result of our study clearly shows that maize grain and stover yields increased proportionally with an increase in $\mathrm{N}, \mathrm{P}$, and $\mathrm{K}$ rates. This confirms the results of Brassard (2007) and Singh et al. (2001). These authors also found that nitrogen is the most limiting nutrient for cereal production in the SubSaharan Africa's soils. As mentioned by previous studies, most of the Africa's soils have low P levels (Koné et al. 2009, 2010) due to the nature and the type of the clays they contain (kaolinite for most of the Acrisols). This shows the importance of the supply of $\mathrm{N}$ and $\mathrm{P}$ to improve maize production in this part of Africa. This could explain the rate of $\mathrm{N}$ applied $\left(80 \mathrm{~kg} \mathrm{ha}^{-1}\right.$ ) suggested by DSSAT model to optimize maize production in these three sites over 30 years simulation.

Performance of DSSAT model in the maize yield simulation in the south and central Benin

The maize grain and the stover yields simulated by DSSAT model fit well with data observed in the field during the two growing seasons (2011 and 2012) for all of the experimental sites. In the Dogbo and Dassa sites, the $\mathrm{R}^{2}$ values between the observed and simulated results were closed to $100 \%$ showing a good performance of the model. There is a strong correlation between the simulated and the observed yields $\left(\mathrm{R}^{2}\right.$ varying between 80 and $91 \%$ for the growing season of 

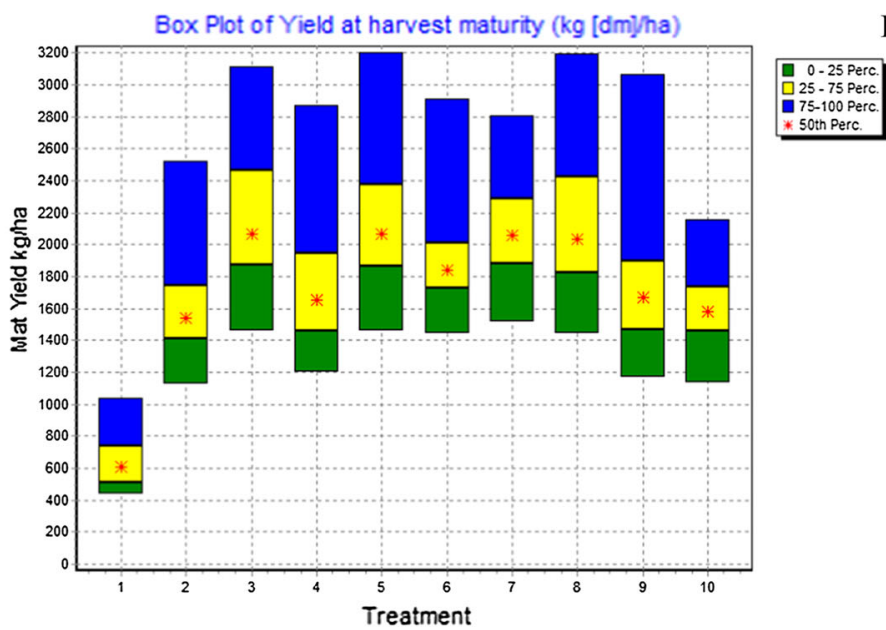

Dogbo

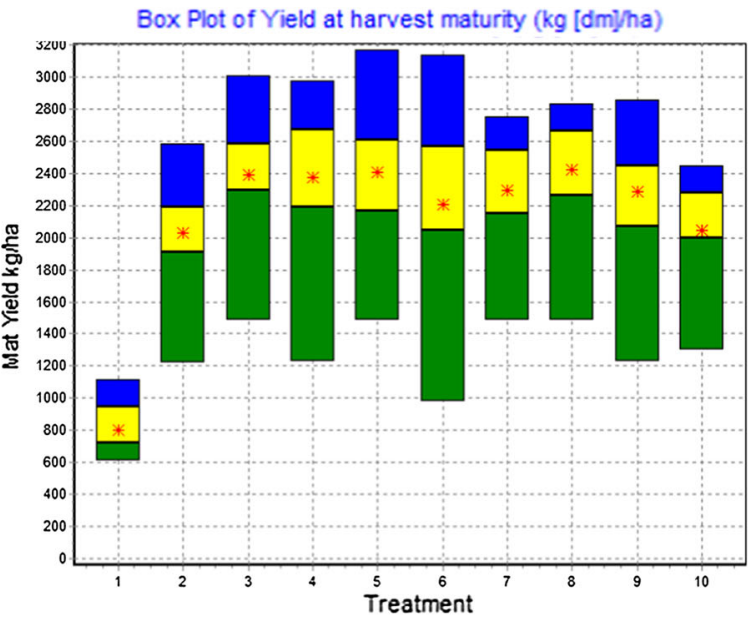

Allada

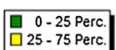

25-75 Perc

* 50th Perc.

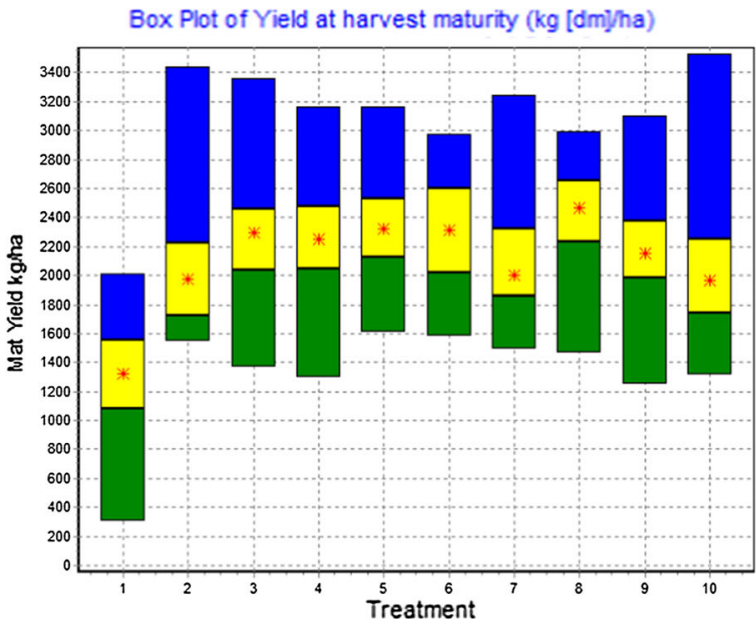

Dassa

Fig. 1 Maize yield as affected by different N-P-K fertilizer rates for 32 years (1980-2012) seasonal and biophysical analysis using 2011 and 2012 growing season grain yields at Dogbo,
Allada and Dassa in Benin. $1=0-0-0 ; 2=44-15-17.5$; $3=80-30-40 ; 4=80-15-40 ; 5=80-30-25 ; 6=80-30-0$; $7=69-30-40 ; 8=92-30-40 ; 9=69-15-25 ; 10=46-15-25$ 
Table 5 Mean-Gini dominance of seasonal partial budget analysis for the different rates of $\mathrm{N}-\mathrm{P}-\mathrm{K}$ fertilizer at Dogbo, Allada and Dassa in Benin
N.B.: $\mathrm{E}(\mathrm{x})=$ Mean monetary return per hectare and $\mathrm{F}(\mathrm{x})=$ Gini coefficient

\begin{tabular}{|c|c|c|c|c|}
\hline Sites & Treatments & $\mathrm{E}(\mathrm{x})\left(\mathrm{F} \mathrm{CFA} \mathrm{ha}^{-1}\right)$ & $\mathrm{E}(\mathrm{x})-\mathrm{F}(\mathrm{x})\left(\mathrm{F} \mathrm{CFA} \mathrm{ha} \mathrm{C}^{-1}\right)$ & Efficiency \\
\hline \multirow[t]{10}{*}{ Dogbo } & $0-0-0$ & 171,950 & $153,906.1$ & No \\
\hline & $44-15-17.5$ & $295,495.4$ & $268,367.8$ & No \\
\hline & $80-30-40$ & $347,673.9$ & $305,963.7$ & No \\
\hline & $80-15-40$ & $299,605.3$ & $246,903.4$ & No \\
\hline & $80-30-25$ & $351,855.3$ & $313,378.4$ & Yes \\
\hline & $80-30-0$ & $324,890.9$ & $292,694.3$ & No \\
\hline & $69-30-40$ & $344,344.5$ & $309,494.2$ & No \\
\hline & $92-30-40$ & $336,991.2$ & $292,092.3$ & No \\
\hline & $69-15-25$ & $320,760.4$ & $265,567.6$ & No \\
\hline & $46-15-25$ & $289,995.0$ & $265,987.4$ & No \\
\hline \multirow[t]{10}{*}{ Allada } & $0-0-0$ & $165,787.9$ & $148,060.6$ & No \\
\hline & $44-15-17.5$ & $339,436.3$ & $307,102.6$ & No \\
\hline & $80-30-40$ & $349,923.9$ & $312,550.1$ & No \\
\hline & $80-15-40$ & $366,509.8$ & $322,382.6$ & Yes \\
\hline & $80-30-25$ & $353,293.2$ & $314,477.7$ & No \\
\hline & $80-30-0$ & $355,165.2$ & $306,664.8$ & No \\
\hline & $69-30-40$ & $338,752.2$ & $302,280.6$ & No \\
\hline & $92-30-40$ & $345,544.2$ & $309,377.9$ & No \\
\hline & $69-15-25$ & $361,416.4$ & $320,968.3$ & No \\
\hline & $46-15-25$ & $340,741.9$ & $310,682.1$ & No \\
\hline \multirow[t]{10}{*}{ Dassa } & $0-0-0$ & $253,612.1$ & $204,617.0$ & No \\
\hline & $44-15-17.5$ & $338,387.8$ & $298,235.2$ & No \\
\hline & $80-30-40$ & $319,172.4$ & $275,081.1$ & No \\
\hline & $80-15-40$ & $339,218.9$ & $292,413.6$ & No \\
\hline & $80-30-25$ & $348,553.8$ & $309,708.7$ & No \\
\hline & $80-30-0$ & $359,916.7$ & $315,749.6$ & Yes \\
\hline & $69-30-40$ & $294,885.5$ & $255,355.6$ & No \\
\hline & $92-30-40$ & $344,829.0$ & $306,441.2$ & No \\
\hline & $69-15-25$ & $344,471.0$ & $300,290.3$ & No \\
\hline & $46-15-25$ & $333,935.9$ & $285,802.9$ & No \\
\hline
\end{tabular}

2011 and 68 and $94 \%$ for the growing season of 2012). These results confirm those of Singh et al. (1999), Dzotsi et al. (2003) in Togo $\left(\mathrm{R}^{2}=83 \%\right)$, Atakora et al. (2014) in the Guinea savannah zone of Ghana $\left(\mathrm{R}^{2}=91.7 \%\right)$ and Tetteh and Nurudeen $(2015)$ in the Sudan Savannah agro-ecology in Ghana $\left(\mathrm{R}^{2}\right.$ between 75 and $99 \%$ ) who found good agreement between the observed maize grain yield and the simulated. The general observation is that the model is very sensitive to fertilizer rates especially $\mathrm{N}$ as mentioned by Tetteh and Nurudeen (2015) and Atakora et al. (2014). It is suggested that for this soil, organic matter improvement should be included in the strategy of soil fertility replenishment.
The value of the standardized mean prediction error (NRMSE) between the observed and simulated results varied between 12.54 and $22.56 \%$ for the 2011 growing season and between 13.09 and $24.13 \%$ for the 2012 growing season. This means that DSSAT model performed well in simulating maize grain yields as the NRMSE values calculated were within the acceptable range (Jamieson et al. 1991; Loague and Green 1991). Our findings showed that the model has performed well, compared to data found by Nurudeen (2011) with NRMSE and $\mathrm{R}^{2}$ values respectively of 26.1 and $91.5 \%$ between the maize grain yields observed and that simulated by the model. This proves that with the correct inputs of soil and varietal 
characteristics a decision support tool like DSSAT can be used to extrapolate fertilizer recommendation data within a large agroecological zone presenting similar climatic characteristics and soil types. The results are also consistent with study carried out by Ritchie and Alagarswamy (2003) and Soler et al. (2007) who found that the CERES-Maize was able to accurately predict the phenology and maize grain yield for a wide range of environmental conditions.

Seasonal and biophysical analysis of the efficiency of the $\mathrm{N}-\mathrm{P}-\mathrm{K}$ fertilizer rates on maize grain yield in the south and central Benin

Fertilizer rates $80-30-25,80-15-40$ and $80-30-0$ presented the best return to investment per hectare and the best efficiency. On the Dassa site, the level of K found presents a risk in the long term. These N-P-K fertilizer rates are far from current standard fertilizer recommendations and do not allow a maize crop to satisfy its nutrient requirements. The fertilizer dose 80-30-0 generated by the model suggested no application of $\mathrm{K}$ at the Dassa site which is not sustainable as it will contribute to $\mathrm{K}$ mining in these soils (the quantity of $\mathrm{K}$ taken up by the plant is not returned to the soil). This N-P-K option should be followed by proper crop residue management and organic manure supply. But considering the Gini coefficient, the net return to investment per hectare calculated for $\mathrm{N}-\mathrm{P}-\mathrm{K}$ fertilizer dose 80-30-25 is sound as far as K application is concerned. The model suggests a uniform rate of $\mathrm{N}\left(80 \mathrm{~kg} \mathrm{ha}^{-1}\right)$ for both soil types. This high quantity of $\mathrm{N}$ suggested by the model denotes the low level of $\mathrm{N}$ in most of the Benin even in West Africa's soils.

During the simulation process, the model did not consider the highest level of $\mathrm{N}\left(92 \mathrm{~kg} \mathrm{ha}^{-1}\right)$ tested as it is provided low net return per hectare due to the relatively low maize grain yields simulated. Furthermore, one can also consider that the DSSAT model has been rational in the economy of $\mathrm{N}$ utilisation by suggesting a reduced quantity. This observation confirms the findings of Fosu et al. (2012) who stated that a supply of high rate of $\mathrm{N}$ leads to $\mathrm{N}$ leaching and possible contamination of water and luxury consumption by the plant while reducing the net return. Despite that the Dogbo and Allada sites are located in the same soil type, almost twice the amount of $\mathrm{P}$ was suggested for the Dogbo site while for Allada site the model suggested an additional application of $\mathrm{K}$. These results reflected land use types which considerably affect fertilizer use efficiency in the farmers' fields (Saïdou et al. 2012).

The lack of difference in maize grain yields found between fertilizer rates 80-30-40, 80-15-40, 80-3025 and $80-30-0$ suggested that whatever the rate of $\mathrm{P}$ and $\mathrm{K}$, the simulated net returns per hectare were similar when $\mathrm{N}$ rate does not vary. This can be explained by the fact that the version 4.5 of DSSAT model is not sensitive to the rates of $\mathrm{K}$ during the simulation process. The model gave a good prediction of $\mathrm{N}$ rate to be applied.

We admit that the 2 years field experiments were not sufficient to derive biophysically optimal fertilizer recommendation rates for each of the sites. In consideration, choice of model-based stochastic approaches combined with economic analyses have been made in the present study. Our results suggest that for intensive maize cultivation the most economically superior N-P-K fertilizer rates are 80-30-25 and 80-15-40 (respectively for Acrisols of Dogbo and Allada in the south) and 80-30-25 (for Ferric and Plintic Luvisols of the Centre). These N-P-K fertilizer rates provide the best net return to investment per hectare.

\section{Conclusion}

It appears from the present study that maize grain yields increase with an evolution of the $\mathrm{N}$ rates in all of the experimental sites. Apart from the control plot, maize yields predicted were very good $\left(\mathrm{R}^{2}\right.$ values more or less close to $100 \%$ ) compared to the field results. In the case of intensive maize cultivation, $\mathrm{N}-$ P-K options 80-30-25 and 80-15-40 (for Acrisols) and 80-30-0 including crop residue management (for Ferric and Plintic Luvisols) were the most economic and efficient fertilizer rates that gave maximum return to investment for farmers. In order to avoid $\mathrm{K}$ mining in the Ferric and Plintic Luvisols as suggested by DSSAT model, an N-P-K fertilizer rate $80-30-25$ was suggested. The way forward is to rerun the model considering different maize cultivars with different growing cycles, combining organic manure with different rates of mineral fertilizer and strategies to improve crop water use efficiency. 
Acknowledgements The authors are grateful to the International Fertilizer Development Centre (IFDC), through the West Africa Fertilizer Program (USAID WAFP) for providing financial support to the present research. We thank the two anonymous reviewers for critically reading the manuscript and providing valuable input.

Open Access This article is distributed under the terms of the Creative Commons Attribution 4.0 International License (http:// creativecommons.org/licenses/by/4.0/), which permits unrestricted use, distribution, and reproduction in any medium, provided you give appropriate credit to the original author(s) and the source, provide a link to the Creative Commons license, and indicate if changes were made.

\section{References}

Acakpo CC (2004) Efficacité agronomique et rationalité paysanne autour de la gestion des fumures minérales et de leurs effets résiduels dans les systèmes de production coton-maïs au centre Bénin. Engineer Thesis, Faculty of Agronomic Science. University of Abomey-Calavi, Benin, p 91

Adégbidi A, Gandonou E, Padonou E, Maliki R, Megnanglo M, Konnon D (2000) Etude des filières des intrants agricoles au Bénin (engrais minéraux, produits phytosanitaires, semences, matériels et équipements agricoles, fertilisants organiques). Tome 2 et 3 . Soil Fertility Initiative (SFI). FAO/World Bank. GIZ, Cotonou, Benin, p 155

Adégbola P, Arouna A (2003) Déterminants socio-économiques de l'adoption des mesures de protection du maïs en stock au Bénin : une application du model logit multinominal. Study report, Programme Analyse de la Politique Agricole (PAPA)/INRAB Porto-Novo, Benin

Atakora KW, Fosu M, Marthey F (2014) Modeling maize production towards site specific fertilizer recommendation in Ghana. Glob J Sci Front Res: D Agric Vet 14(6):70-81

Balogoun I, Saïdou A, Ahoton LE, Adjanohoun A, Amadji GL, Ezui G, Youl S, Mando A, Igué AM, Sinsin BA (2013) Détermination des formules d'engrais et des périodes de semis pour une meilleure production du maïs (Zea mays L.) au Sud et au Centre Bénin. Bulletin de la Recherche Agronomique du Bénin (BRAB) Numéro Spécial Fertilité du maïs-Janvier, pp 1-11

Brassard M (2007) Développement d'outils diagnostiques de la nutrition azotée du maïs-grain pour une gestion optimale de l'engrais azoté. Mémoire de maîtrise. Université de Laval, Quebec, p 105

DeJonge KC, Kaleita AL, Thorp KR (2007) Simulating the effects of spatially variable irrigation on corn yields, costs, and revenue in Iowa. Agric Water Manage 92(1-2):99-109

Diallo B, Dembélé N, Staatz J (2012) Compétitivité du maïs local en Afrique de l'Ouest depuis la hausse des prix alimentaires mondiaux. PRESAO. Résultats de recherche $\mathrm{N}^{\circ}$ 2-2012-5, p 13

Du Toit AS, Booysen J, Human HH (2001) Use of Linear regression and a correlation matrix to evaluate CERES3 (Maize). In: White JW, Grace PR (eds) Modeling extremes of wheat and maize crop performance in the tropics.
Proceedings of a workshop, CIMMYT, El Batan (Mexico), 19-22 April, Mexico, D.F. CIMMYT

Dugué P (2010) Etude d'évaluation environnementale et du développement de systèmes de production durables dans le cadre des projets de soutien à la production vivrière (Bénin, Togo, Ghana). FARM CIRAD, Ghana, p 135

Dzotsi K (2002) Application du modèle CERES-maize de DSSAT à l'analyse de stratégies de semis pour le maïs (Zea mays L.) dans les conditions de Sévé-Kpota. Engineer thesis, Higher School of Agronomy, University of Lomé, Togo, p 92

Dzotsi K, Agboh-Noaméshie A, Struif Bontkes TE, Singh U, Dejean P (2003) Using DSSAT to derive optimum combinations of cultivar and sowing date for maize in southern Togo. In: Struif Bontkes TE, Wopereis MCS (eds) Decision support tools for smallholder agriculture in Sub-Saharan Africa: apractical guide. IFDC/CTA, Wageningen, pp 100-113

Ezui G, Igué AM, Attiogbe P, Mando A, Sogbedji JM, Pare T, Youl S, Wilkens P, Singh U, Gist O (2011) Mise à jour de recommandations d'engrais pour la production du maïs en Afrique de l'Ouest: Cas du Bénin, Poster. IFDC Lomé, Togo

FAO (2006) World reference base for soil resources, 2nd edn. World Soil Ressources Reports No. 103. Food and Agriculture Organization of the United Nations, Rome, Italy

FAOSTAT (2007) Statistical database. www.aginternetwork. org. Accessed 20 May 2015

FAOSTAT (2013) Statistical database. www.aginternetwork. org. Accessed 20 May 2015

FAOSTAT (2014) Statistical database. www.aginternetwork. org. Accessed 20 May 2015

Fosu M, Buah SS, Kanton RAL, Agyare WA (2012) Modeling maize response to mineral fertilizer on silty clay loam in the Northern Savanna zone of Ghana using DSSAT model. In: Kihara $\mathrm{J}$ et al (eds) Improving soil fertility recommendations in Africa using the Decision Support System for Agrotechnology Transfer (DSSAT). Springer, Dordrecht, pp 157-168

Giller KE (2002) Targeting management of organic resources and mineral fertilizers: can we match scientists' fantaisies with farmers' realities? In: Vanlauwe B, Diels J, Sanginga $\mathrm{N}$, Merckx R (eds) Integrated plant nutrient management in Sub-Saharan Africa: from concept to practice. CAB International, Wallingford, pp 155-171

He J, Porter C, Wilkens P, Marin F, Hu H, Jones JW (2010) Guidelines for installing and running GLUE program. In: Hoogenboom G, Jones JW, Wilkens PW, Porter CH, Boote KJ, Hunt LA, Singh U, Lizaso JL, White JW, Uryasev O, Royce FS, Ogoshi R, Gijsman AJ, Tsuji GY (eds) Decision support system for agrotechnology transfer (DSSAT) version 4.5 [CD-ROM]. University of Hawaii, Honolulu

Igué AM (2000) The Use of Soil and Terrain Digital Database for Land Evaluation Procedure Case study of Central Benin. Dissertation, Hohenheimer Bodenkundliche Hefte, Heft N 58 University of Hohenheim, Stuttgart, Gemany

Igué AM, Adjanohoun A, Saïdou A, Ezui G, Attiogbe P, Kpagbin G, Gotoechan-Hodonou H, Youl S, Pare T, Balogoun I, Ouedraogo J, Dossa E, Mando A, Sogbedji JM (2013) Application et adaptation de l'approche intégrée DSSAT-SIG à la formulation des doses d'engrais pour la 
culture du maïs au Sud et au centre du Bénin. Bulletin de la Recherche Agronomique du Bénin (BRAB), Numéro spécial Fertilité du maïs, pp 24-33

Jamieson PD, Porter JR, Wilson DR (1991) A test of the computer simulation model ARC-WHEAT1 on wheat crops grown in New Zealand. Field Crops Res 27:337-350

Jones CA, Kiniry JR (1986) CERES-maize: a simulation model of maize growth and development. Texas A\&M University Press, College Station

Jones JW, Hoogenboom G, Porter CH, Boote KJ, Batchelor WD, Hunt LA, Wilkens PW, Singh U, Gijsman AJ (2003) The DSSAT cropping system model. Eur J Agron 18:235-265

Koné B, Diatta S, Saïdou A, Akintayo I, Cissé B (2009) Réponses des variétés interspécifiques du riz de plateau aux applications de phosphate en zone de forêt au Nigeria. Can J Soil Sci 89:555-565

Koné B, Saïdou A, Camara M, Diatta S (2010) Effet de différentes sources de phosphate sur le rendement du riz sur sols acides. Agron Afr 22(1):55-63

Loague K, Green RE (1991) Statistical and graphical methods for evaluating solute transport models: overview and application. J Contam Hydrol 7:51-73. https://doi.org/10. 1016/0169-7722(91)90038-3

Miao Y, Mulla DJ, Batchelor WD, Paz JO, Robert PC, Wiebers M (2006) Evaluating management zone optimal nitrogen rates with a crop growth model. Agron J 98(3):545-553

Nurudeen AR (2011) Decision Support System for Agro-technology Transfer (DSSAT) model simulation of maize growth and yield response to NPK fertilizer application on a benchmark soil of Sudan savanna agroecological zone of Ghana. Master of Science thesis, Department of Crop and Soil Sciences, Faculty of Agriculture, Kwame Nkrumah University of Science and Technology Kumasi, Ghana, p 151

Pieri C (1989) Fertilité des terres de savanes: Bilan de trente ans de recherches et de Développement agricoles au sud du Sahara. Ministère de la Coopération et CIRAD-IRAT, Paris, p 444

Ritchie JT, Alagarswamy G (2003) Model concepts to express genetic differences in maize yield components. Agron J 95:4-9

Saïdou A, Janssen B, Temminghoff EJM (2003) Effects of soil properties, mulch and NPK fertiliser on maize yields and nutrient budgets on ferralitic soils in southern Benin. Agric Ecol Environ 100:265-273

Saïdou A, Kossou D, Acakpo C, Richards P, Kuyper WT (2012) Effects of farmers' practices of fertilizer application and land use types on subsequent maize yield and nutrient uptake in central Bénin. Int J Biol Chem Sci 6(1):365-378
Sanchez PA, Palm CA, Szott LT, Cuveas E, Lal R (1989) Organic input management in tropical agroecosystems. In: Coleman DC, Oades JM, Uehara G (eds) Dynamics of soil organic matter in tropical ecosystems. University of Hawaii Press, Honolulu, pp 125-152

Singh U, Wilkens PW (2001) Simulating water and nutrient stress effects on phenological developments in maize. In: White JW, Grace PR (eds) Modeling extremes of wheat and maize crop performance in the tropics. Proceedings of a Workshop, CIMMYT, El Batán, Mexico, 19-22 April 1999

Singh U, van Reuler H, Dejean P (1999) Using decision support systems to stimulate resource conserving practices. Paper presented at the MODSS'99 conference, Brisbane, Australia, 1-6 Aug 1999

Singh U, Diels J, Henao J, Breman H (2001) Decision support systems for improving the application of integrated nutrient management technologies. In: Payne WA, Keeney DR, Rao SC (eds) Sustainability of agricultural systems in transition. Crop Science Society of America and Soil Science Society of America, Madison, pp 305-321

Soler CMT, Sentelhas PC, Hoogenboom G (2007) Application of the CSM-CERES-Maize model for planting date evaluation and yield forecasting for maize grown off-season in a subtropical environment. Eur J Agron 27:165-177

Tetteh MF, Nurudeen RA (2015) Modeling site-specific fertilizer recommendations for maize production in the Sudan savannah agroecology of Ghana. Afr J Agric Res 10(11):1136-1141. https://doi.org/10.5897/AJAR2013. 7413

Thorp KR, Batchelor WD, Paz JO, Kaleita AL, DeJonge KC (2007) Using cross-validation to evaluate CERES-Maize yield simulations within a decision support system for precision agriculture. Trans ASAE 50(4):1467-1479

Thorp RK, DeJonge CK, Kaleita LA, Batchelor DW, Paz OJ (2008) Methodology for the use of DSSAT models for precision agriculture decision support. Comput Elect Agric 6(4):276-285

Toléba-Séidou M, Biaou G, Saïdou A, Zannou A (2015) Fonctionnement de la filière maïs au Bénin. Cahier du CBRST, Cotonou (Bénin) 7(1):35-73

Weller U (2002) Land evaluation and land use planning for Southern Benin (West Africa). Dissertation Hohenheimer Bodenkundliche Hefte, Heft No. 67, University of Hohenheim, Stuttgart, Germany, p 166

Zeller M, Sharma M, Henry C, Lapenu C (2006) An operational method for assessing the poverty outreach performance of development policies and projects: results of case studies in Africa, Asia, and Latin America. World Dev 34(3):446-464 